\title{
Editorial: Central European Legal Culture BETWEEN TRANSITION AND CONTINUITY
}

\author{
RAFAL MAŃKO*
}

The present special issue of the Wroclaw Review of Law, Administration and Economics brings together papers devoted to contemporary problems of the Central and Eastern European legal space. These problems are confronted with different methodological approaches, including historical, theoretical and doctrinal (dogmatic) research.

The first paper in this volume makes a programmatic statement in favour of analysing Central Europe as a single legal space (in terms of legal culture), distinct both from legal culture to the east and west of our region. The paper by Rafał Mańko, Martin Škop and Markéta Štěpáníková, makes a claim in favour of the legal identity of Central Europe as a legal family (Rechtskreis), distinct from Western Europe on the one hand, and the post-Soviet legal space, on the other hand.

The second paper, written by Jānis Pleps, is devoted to the The Continuity of the Constitutions in the Baltic States. The author analyses the renewal of the constitutions in Latvia, Lithuania and Estonia after the division of the USSR. As he rightly points out, the renewal of the old constitutions is an infrequent event in the world. In the specific context of the three Baltic States, the restoration of the old constitution had symbolic and political importance, reinforcing the doctrine of state continuity and legitimizing the new constitutional order after the transformation.

The third paper by Aleksandra Gliszczyńska-Grabias and Anna Śledzińska-Simon is devoted to Victimhood of the Nation as a Legally Protected Value in Transitional States - Poland as a Case Study. Just like the paper by Jānis Pleps, Gliszczyńska-Grabias and Śledzińska-Simon look at the legal connections between current Central European legal life and its history. The co-authors point out that the memory of the past is always vital for building national identity in transitional contexts. Yet, the preservation of a particular representation of the national history may lead not only to distortion of the self-identification process, but also to distortion of rights protection. Taking Poland as a case study, they aim at explaining mechanisms of using criminal laws for historical assessment and show

DOI: $10.1515 /$ wrlae-2018-0001

* PhD in Law (Amsterdam). External Fellow, Centre for the Study of European Contract Law, University of Amsterdam. Email: r.t.manko@uva.nl. 
instances when victimhood became a legally protected value used to justify limitations of free speech and academic research.

The fourth paper by Aleksandra Kustra is entitled The Polish Constitutional Court and Political "Refolution" after 1989: Between Continuity and Discontinuity of the Constitutional Narrative. The author also continues the topic of the role of the past in the law, observing that 'regardless of the stage of the political transition, both the constitutioncreators and the constitutional judiciary tend to distance themselves from the past'. As an example, she cites the case-law of the Polish Constitutional Court. Nonetheless, on the basis of an in-depth analysis she comes to the conclusion that this case-law actually 'reveals salient elements of continuity that blot the white sheet of the brand new constitutional narration'.

In the fifth paper, Konrad Kobyliński analyses The Polish Constitutional Court from an Attitudinal and Institutional Perspective Before and After the Constitutional Crisis of 2015-2016. Kobyliński analyses the question of dissenting opinions at supreme courts in general, before applying these considerations to the Polish Constitutional Court. He draws preliminary comparative remarks considering three periods in the history of the Court: the pre-1989 period, the period between 1990 and 2015, and the period following the constitutional crisis of 2015-2016.

The subsequent paper by Rafał Mańko is entitled Towards a Typology of Dimensions of Continuity and Discontinuity of Law: The Perspective of Polish Private Law after the 1989 Transformation. The aim of his paper is to propose a typology of dimensions of continuity (or discontinuity) of law which would allow to compare different legal cultures, areas of law and legal systems. The paper focuses on the following dimensions: structure of the law, conceptual framework, fundamental principles, legal institutions and rules.The theoretical framework proposed in the paper is illustrated by references to Polish private law following the 1989 transformation.

The remaining papers in this special issue are devoted to specific legal issues, viewed from the angle of continuity/discontinuity, nonetheless in the context of specific (doctrinal) areas of research into law. Thus, Katarzyna Bomba analyses Union Solidarity in Eastern and Central Europe Using the Example of Poland. She examines the extent of union solidarity in post-communist European countries from the example of Poland with a particular focus on the impact of the 1989 transformation. She concludes that instead of seeking to modify the model of bargaining or replacing trade unions with other forms of employee representations, one should rather prefer the option of strengthening the social position of trade unions through improving the existing legal framework. The paper by Ewa Wójcicka is concerned with The Right of Petition in the Republic of Poland - New Challenges and New Solutions. Dr Wójcicka's paper aims at presenting and analysing the legal views of the petition right specified expressly in Article 63 of the Polish Constitution. In the first instance her article concentrates on the review of petitioning genesis in Europe and the functions of this right. Then, she discusses the process of restoration of the institution of petition in the Polish legal system, the prevailing conceptions of the petition right, and then subjective and objective scope of the right of petition. 
The penultimate paper, written by Paulina Bieś-Srokosz, is devoted to the issue of Transformation of Administrative Law through Legal Transfers: The Case of Government Agencies in post-1989 Poland. The author points out that as a result of the political transformation of 1989 a number of new public administration bodies were established in Poland, observing that the transformation 'sort of forced the public administration to adjust to the new "reality" by performing public tasks which had not been stipulated by the law' of the period of Actually Existing Socialism. Therefore, the legislature resorted to legal borrowing, introducing into Polish law a number of legal transplants from Western law. In BieśSrokosz's opinion, however, this legal borrowing 'was done hastily and inconsistently' which she subjects to a thorough critique in her paper.

The final paper included in the volume was written by Jacek Srokosz and is devoted to Marketisation of Universities and Legal Education in Poland: The Balance 25 Years after the Transformation. Srokosz discusses two opposing paradigms of legal education - the humanist approach and the practical approach in the context of marketisation which occurred after Poland's transformation from Actually Existing Socialism to capitalism in 1989.

We hope that this special issue of the Wroclaw Review of Law, Administration and Economics will be well received and will constitute a starting point for further discussion on the legal identity of Central Europe as a space of legal culture, especially in the context of its common legal traditions and common elements of today's legal life. 